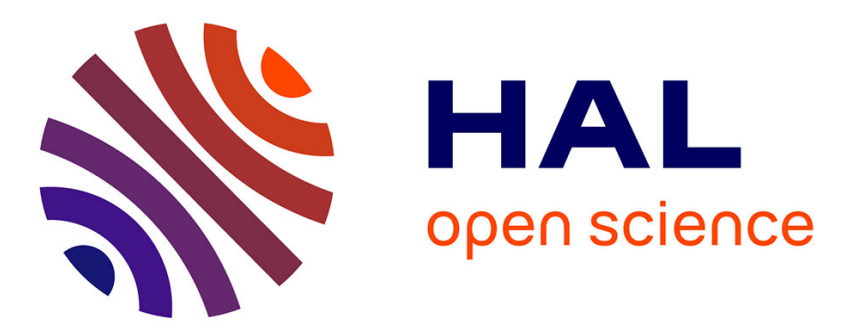

\title{
Julier A. P., 2013, Eating Together: Food, Friendship, and Inequality, Urbana, University of Illinois Press, 256
}

p.

\author{
Isabelle Darmon
}

\section{- To cite this version:}

Isabelle Darmon. Julier A. P., 2013, Eating Together: Food, Friendship, and Inequality, Urbana, University of Illinois Press, 256 p.. Review of Agricultural, Food and Environmental Studies, 2016, 97 (1), pp.67-69. 10.1007/s41130-016-0004-7 . hal-03114827

\section{HAL Id: hal-03114827 \\ https://hal.science/hal-03114827}

Submitted on 19 Jan 2021

HAL is a multi-disciplinary open access archive for the deposit and dissemination of scientific research documents, whether they are published or not. The documents may come from teaching and research institutions in France or abroad, or from public or private research centers.
L'archive ouverte pluridisciplinaire HAL, est destinée au dépôt et à la diffusion de documents scientifiques de niveau recherche, publiés ou non, émanant des établissements d'enseignement et de recherche français ou étrangers, des laboratoires publics ou privés. 


\title{
Julier A. P., 2013, Eating Together: Food, Friendship, and Inequality, Urbana, University of Illinois Press, 256 p.
}

\author{
Isabelle Darmon ${ }^{1}$
}

Published online: 4 April 2016

(C) INRA and Springer-Verlag France 2016

Eating Together is a welcome contribution to the understudied theme of contemporary food sociability — not only as form but also as site for wider processes of social differentiation, inclusion and exclusion. Alice Julier is there in conversation with Mary Douglas's reflections on boundaries of intimacy and distance marked around food events in the home, Marjorie DeVault's analysis of feeding as gendered performance and Alan Warde and Lydia Martens' study of the 'communal mode' of eating out.

The book was going to be entitled Things taste better in small houses (followed by the current subtitle), a sentence allegedly proffered by Queen Victoria and a reflection of the importance of form and format in the book. Indeed, the other main author to whom Julier refers in key stages of her exposition is Georg Simmel, especially concerning the type of sociability afforded by different forms of food-related events (notably of different sizes). A neat summary of the main theses of the book is provided on p. 207: 'In sum, people create bonds of intimacy with some degree of choice in non-kin relationships, using food and the household as material sites for its enactment. At the same time, the form of the event, the kind of food served, who prepares it, and how it is served indicate the nature of the relationships being created'. Thus, the main concern of the book is to establish food-based sociability with 'non-kin' as a locus for the reproduction of class, race and gender divides through specific performances as well as, in principle, for challenging these: the dilution of general norms of sociability seems to create more space for

Isabelle Darmon

Isabelle.Darmon@ed.ac.uk

1 School of Social and Political Science, The University of Edinburgh, Edinburgh, UK interpretation of 'cultural templates' (Warde and Martens 2000: 61) and thus also, according to the author, for the 'subversion' of implicit roles and relationships.

Based on the ethnographic study of six networks of friends and acquaintances across 35 households, and repeated interviews with 47 individuals from these households and networks, the three central chapters of the book explore the link between modes of 'sociation' (Simmel) and the reproduction of inequality. Each addresses a different configuration-from the paradigmatic template of the 'dinner party' and its contemporary variations (chapter 3 ) to the also rather well defined yet much more informal template of 'potlucks' (chapter 5), via a wealth of less-defined forms (chapter 4). Food-related social forms are thus investigated both in terms of their affordance of sociability and politically - as 'inviting strangers - or others of any sort - into the domestic environs is a highly political and personal act, one that connects to citizenship, rights, individualism and subjecthood' (p. 186).

Chapter 2 discusses comfort as the relatively new regulatory idea for contemporary sociability events in the USA and as a key operator of sociability. Comfort is articulated in different ways in different circles with notions of intimacy and distance, formality and informality. Although subject to variations, 'the ethos of comfort suggests that sociable moments often mirror the intimacy of family life' (p. 28). The author documents this shift of ethos through the striking evolution of the representation of food events in étiquette and entertaining books - from the formal affairs in which food has an instrumental role, in Emily Post's étiquette book for dinner parties (widely read in between the two world wars in the States), to the aesthetic feasts focused on the experience of food, display and style, in Martha Stewart's 1982 book, Entertaining. The study of étiquette books has a nice sociological pedigree. They are key to understanding cultural templates from which people draw to organise their dinner parties, and can be seen as 
vehicles for the 'codification' of 'relations of ruling' (after Dorothy Smith) (p. 12): indeed, Alice Julier chose to study these two books more particularly because they were regularly referenced by her respondents (including critically). Nevertheless, one would want to widen the exploration of cultural templates today and approach understandings of hospitality through a wider range of sources, to capture the diffuse nature of these references.

Chapter 3 is an account of contemporary performances of dinner parties - nicely unravelling the workings of the template as well as respondents' way of playing with it. That template is one of the formalized (e.g. seated) events, requiring certain resources, in particular economic. The author shows the persistence of existing lines of gender division across the array of performances of dinner parties reviewed. In particular, as they become events in which food is not a mere vehicle anymore but a focus of attention, an old distinction between daily and extra-ordinary provision of food is reenacted in a new way: men take more often centre stage (sometimes literally so: staging themselves as cooks in the kitchen under the admiring gaze of visitors) whilst women do most of the backstage work of maintaining contacts over time etc. This is not new knowledge, but it is instructive to set this against the background of variations from the cultural template. In connection with this, the variations from the classical model (presented first) also display a shift toward the aestheticization of food and dinner parties as they become invested with imagination, creativity and desire and are viewed as something to experience, rather than as a series of elaborate codes and rules to merely interpret and execute. Indeed, this is where some analysis of class comes into play, as food becomes a new area for the acquisition of cultural capital. For example, interest in and knowledge about food and cooking allows some of the couples interviewed to 'secure membership in their class' despite lower incomes.

Chapter 4 explores sociable meals without a direct template and which therefore require some negotiation towards a 'shared understanding' (Warde and Martens 2000:61). Such negotiation takes various avenues, a frequent one today being through questions to the host regarding what should be brought. For first-time guests, much can be gathered in that exchange over contributions, as to what kind of event they have been invited to. The chapter does a fine job of drawing the consequences of such absence of normative definitions of the events - in particular regarding the perhaps more immediate understanding of reciprocity deriving from the absence of an orchestration of mutual obligations such as the one afforded by the hosting of dinner parties. The author notes a certain anxiety for contributing, especially from people whose level of income makes it difficult to host a meal. And it is an additional required skill of the host to know how to reassure people that they have contributed enough, and well. One of the interviewed hosts, for example, includes preparation work in the event itself, distributing roles to guests, both for that purpose and as an 'ice-breaker'. Other areas of uncertainty and negotiation include the number of guests and the place of commercial foods, both of which allow hosts to juggle with their particular (economic or time) constraints.

Julier thus describes a whole economy of hospitality, which has ideally to take all of these constraints and areas of negotiation into account. Some of these areas of negotiation are also more accessible to certain social groups than othersas, for example, the use of commercial foods is still equated with deficient caring work, unless one has the means to buy high quality 'home like' foods. The extent, role and place of commercial foods and commodification are an interesting contribution of this chapter-e.g. regarding acceptability through incorporation and customization. 'Economy' however is not the word used by the author to designate the juggling with constraints and expectations. She prefers to refer to 'work' to indicate that the burden of managing that economy is placed chiefly on the host-mostly the hostess. The chapter thus concludes with the remark that class and gender distinctions also operate in less conventionalized formats than the dinner party.

Chapter 5 turns to potlucks (where each guest contributes a dish or food item), which, by contrast with the social forms addressed in chapter 4 , are relatively well-defined eventsthrough the 'shared - but separate - labor' required for these 'communal social meal[s]' (p. 148). Emphasis is on abundance, variety and uncertainty: potlucks are festive events that break the routine pattern and structure of meals.

It is potlucks which spurred Julier to write her book-understandably so since their format and purpose ('constructing temporary unities' amongst socially heterogeneous people) (p. 150) lends itself better to the kind of political questions the author was keen to ask to food sociability. On the continuum between private and public events in which the events analysed in Julier's book fall, potlucks are more decidedly towards the public pole as they concern church-, sportsor work-based communities. Other communities of purpose reviewed in the book include one AA, which was particularly interesting for the class heterogeneity of participants.

For the creation of such sense of unity across difference, place seems to matter at least as much as food. Though many potlucks take place in community spaces or at work, Julier examined potlucks taking place in the home of one of the individual members. Such hosts then perform a role for the whole of the community; they are the momentary facilitators of the community spirit so to speak, perhaps simply because they are the only members with a house large enough. In one case, the form of the potluck seemed to transfigure the notions of place and home, as guests were given sets of keys and were told to use the house as their second home - an extreme manifestation of what could be called the 'potluck spirit'! But that spirit is also dependent on the contribution of each, which 
places certain obligations on guests. Thus, in that same potluck circle, some guests were well known for their habit of bringing their specialty beers and this was frowned upon as snobbishness, as very few other guests appreciated such drinks and bringing such beers therefore meant disregarding the implicit rule of trying to cater for the community as a whole, or at least a majority (p. 181-182): the demand for dishes and drinks suitable for accommodating a variety of tastes thus seems to remain a constant of domestic hospitality, whether this obligation is placed on the cook in formal dinner parties or on guests contributing to a potluck.

Alice Julier discusses the claim, made by some authors, e.g. Joseph Gusfield, that potlucks are more egalitarian, and, interestingly, decides that whilst the features of potlucks do make them amenable to more equal roles, they cannot be assessed on their own as often guests will overlap between different types of social occasions. By affording a type of sociability which becomes problematic in another context, and by gathering people together who may or may not be invited to other types of parties, 'the potluck involves both a suspension and a reinforcement of status' (p. 163).

Chapter 6 returns to the various strands of the investigation and, complementing it with the literature, seeks to come to some conclusions concerning the link between forms of sociability and their 'politics' ('opportunities for equality'). The author finds that the increasing 'ideology of comfort and informality' (which, as the author points out, are not equivalent) is not necessarily conducive to more equality, as 'people's performances of class and gender combined in ways that reflected the more institutionally structured aspects of their lives' (p. 188). Warde and Martens had already pointed out the informalisation of eating (Warde and Martens 2000: 14). More generally, ties with non-kin are often circumscribed by class and race, and dependent on women's labour for their existence and maintenance: friendship may appear to be voluntary (Jerrome 1984) but it is also of course a 'structured choice' (p. 190).

This concluding chapter thus not only sums up some of the main contributions of the book, but also shows some of its main limits.

Friendship is a particularly intriguing and productive lens to study configurations of the private and the public in different societies-as suggested, for example, by the work of Helena Tuomainen (2014) on commensality amongst Ghanaians in London, where commensality takes place in public events of the community, whereas the family shares food without eating together. Julier's study interestingly shows a very different state of affairs in the USA (perhaps generalizable to western societies), where the reference aspired to is the intimacy of family life - and where what is sought out with friends is a proximity which makes them close to kin, with variable, 'negotiated', restraints on this.

Her investigation of race and class remains limited, in part due to the design of the study - mostly centred on performances rather than on the constitution of networks of acquaintances and their selection for particular events, and also rather surprisingly centred on the hosts, despite the author's interviews with guests of the same circles. Respondents were clearly drawing on class-based resources and reproducing class in their 'sociations' but it is difficult to go further than this. Conclusions about persisting gender inequalities, even though their form has been reshuffled, are more solid as the author can there rely much more on the analysis of performance carried out throughout the book.

One is left sceptical about a key area of questioning of the book - the link between forms of sociability and politics, due to the at times inflated language and aggrandizement of claims: some dinner parties are presented as 'subversive', for example, when the rules of the dinner party are explicitly played with and parodied, or where kin and non-kin are invited together (this is also something that Julier examines with regard to potlucks). Bringing kin and non-kin together around the table may be unusual, and go against implicit rules of the game and conceptions of 'intimacy and distance' (chapter 5, p. 167), but how is this subversive - and of what?

Finally, although this is an empirically rich book, it can also be difficult to read at times, as the author appears to be the victim of her own (commendable!) quest for egalitarianism: this leads her to never raise a point without at the same time raising another one for equal consideration, thus constantly shifting the focus and not always achieving much analytical or conceptual progress.

Overall, however, it is well worth following Alice Julier on this journey and exploration of eating together through forms, ethos and places.

\section{References}

Jerrome D (1984) Good company: the sociological implications of friendship. Sociol Rev 32(4):696-718

Tuomainen H (2014) Eating alone or together? Commensality among Ghanaians in London, Anthropology of Food, S10, URL: http:// aof.revues.org/7718

Warde A, Martens L (2000) Eating out: social differentiation, consumption and pleasure. Cambridge University Press, Cambridge, 260 p 